Greek Medical Manuscripts

Diels' Catalogue

Tome 1: Diels' Catalogue with Indices 


\title{
Medical Traditions
}

\author{
Edited by \\ Alain Touwaide \\ Scientific Committee \\ Michael Friedrich, Jost Gippert, Marilena Maniaci, \\ Paolo Odorico, Steve M. Oberhelman, \\ Dominik Wujastyk
}

Volume 2/1

De Gruyter 


\section{Greek Medical Manuscripts Diels' Catalogue}

Tome 1: Diels' Catalogue with Indices

Newly revised and updated by

Alain Touwaide 
ISBN 978-3-11-060064-3

e-ISBN (PDF) 978-3-11-059996-1

ISSN 2567-6938

Library of Congress Control Number: 2020945916

Bibliographic information published by the Deutsche Nationalbibliothek

The Deutsche Nationalbibliothek lists this publication in the Deutsche Nationalbibliografie; detailed bibliographic data are available on the Internet at http://dnb.dnb.de.

(C) 2021 Walter de Gruyter GmbH, Berlin/Boston

Cover image: Collage of illustrations in medical treatises from the 1st to the 16th century CE, from Greece and Rome, to the Arabic World and China.

Printing: CPI books GmbH, Leck

www.degruyter.com 